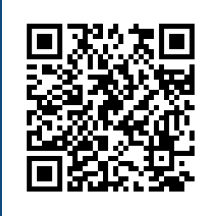

Keywords:

Bioma

Planted forest

Succession

Symbiotic association
Historic:

Received I | /09/2018

Accepted 25/03/2019
+Correspondence: etienne.winagraski@gmail.com
Etienne Winagraskila+, Glaciela Kaschuk ${ }^{1 b}$, Pedro Henrique Riboldi Monteiro'c, Celso Garcia Auer ${ }^{2 a}$, Antônio Rioyei Higald

\section{DIVERSITY OF ARBUSCULAR MYCORRHIZAL FUNGI IN FOREST ECOSYSTEMS OF BRAZIL: A REVIEW}

WINAGRASKI, E.; KASCHUK, G.; MONTEIRO, P. H. R.; AUER, G.; HIGA, A. R. Diversity of arbuscular mycorrhizal fungi in forest ecosystems of brazil: a review. CERNE, v. 25, n. I, p. 25-35, 2019.

\section{HIGHLIGHTS}

Brazilian forest ecosystems carry ubiquitous and rare species of arburcular mycorrhiza fungi (AMF).

The method of spore morphology underestimates AMF diversity in forest ecosystems.

The AMF are not specific to host-plant but to the environments where plants grow.

Ubiquitous AMF species may be a source of AMF inocula for forests.

\section{ABSTRACT}

Plants can stablish symbiosis with arburcular mycorrhiza fungi (AMF), in which the fungus uses carbohydrates synthesized by plant photosynthesis in exchange for soil nutrients. AMF symbiosis may benefit plants by increasing the rates of nutrient uptake, tolerance to abiotic stresses, protection against pathogens and, by promoting resilience of forest species to adverse conditions. Knowledge about the diversity of mycorrhizas may help stablish relationships of species selection, AMF production and inoculation. Therefore, the objective of this review is to compile information to identify existing patterns in AMF diversity in Brazilian forest ecosystems. Compilation was based in 74 articles (in English, Portuguese and Spanish languages) searched in the Web of Knowledge and selected for having the keywords "forest", "diversity", "mycorrhizal" and "Brazil", and that identified AMF species by spore morphology. Compilation resulted in a list of I64 AMF species and indicated that AMF species are not plant host specific but they are selected by environmental conditions where the host grows. Some AMF species were ubiquitous and some were rare in forest ecosystems. Rare AMF species may be an artefact of AMF identification because, in comparison to molecular tools, spore morphology may underestimate AMF diversity. Four AMF species, Acaulospora scrobiculata, Acaulospora foveata, Clareoideglomus etunicatum and Glomus macrocarpum, were ubiquitous to several biomes, existed in different stage of forest succession and seemed to be adapted to different forest managements. Therefore, $A$. scrobiculata, A. foveata, A. mellea, C. etunicatum and $G$. macrocarpum could have potential to be used as AMF inoculant in forest species.
' Federal University of Paraná, Curitiba, Paraná, Brazil - ORCID: 0000-0002-9349-8842ª 0000-0002-8993-6563 0000-0003-| 1754-972 |c, 0000-000 |-8486-06 | |d

2 Embrapa Florestas, Curitiba, Paraná, Brazil - ORCID: 0000-0002-49|6-2460ª 


\section{INTRODUCTION}

Plants can grow in many inhospitable environments because they can stablish symbiotic association with mycorrhizae fungi. In the mycorrhizal plant-fungi symbiosis, the fungus uses carbohydrates synthesized by plant photosynthesis in exchange for soil nutrients. Mycorrhizal fungi grow in the root systems and form extrarradical hyphae that increase the soil volume in which roots can absorb water and nutrients. The mycorrhizal symbiosis results in greater rates of nutrient plant uptake (the most notable being phosphate), improves plant tolerance to abiotic stresses like water stress, soil acidity and high temperatures. Mycorrhizal fungi also increases plant protection against phytopathogens as mycorrhizal fungi occupy the root space that could be infected by pathogen fungi. Therefore, mycorrhizal symbiosis may promote greater resilience of forest species under adverse environmental conditions, for example, helping rehabilitation of degraded areas by increasing biomass and plant nutrition (Vozzo et al., 197I, Skujins; Allen, 1986). In addition, mycorrhizal fungi are also important to determine the composition of plant species in plant community as mycorrhizal symbiosis improves plant growth stability under soil stressful condition (Gange et al., 1993, Van Der Heijden et al.,(1998).

Robert Hartig in 1840 was the first to describe mycorrhizal association but he considered mycorrhizal fungi to be root parasites. Later, in 1885, Albert Bernard Frank conceptualized the mycorrhizal symbiosis as it is known today. From that point forward, paleobotanical, morphological and phylogenetic data have demonstrated that plants and mycorrhizal fungi have coevolved more than 400 million years ago (Brundrett, 2002). There are at least three types of mycorrhizal symbioses: ectomycorrhizal (when mycelia grow outside the root tissues), endomycorrhizal (when mycelia grow inside the root tissues) and ecto-endomycorrhizal (when both types of mycelia growth occur).

Arbuscular mycorrhizal fungi (AMF) are endomycorrhizal symbiotic filamentous fungi that form mycelia and special structures called arbuscles inside the root cells. AMF encompasses hundreds species belonging to the Kindgon of Fungi and Phylum of Glomeromycota, which may colonize about $80 \%$ of terrestrial plants (Smith; Read, 2008). The AMF species richness is related to the plant host richness in the ecosystem. Increases in AMF-plant richness increase the abundance of hyphae in the soil, which in turn, increase the plant nutrient uptake and growth (Van Der Heijden et al., 2008). Therefore, there is a possible relationship between the richness of
AMF and the composition of forest species in different environments and different forest succession (Janos, 1980a,b; Zangaro et al., 2000; Uibopuu et al., 2009; Kikvidze et al., 2010; Shi et al., 2016). AMF colonization is ubiquitous as they were found in dunes (Assis et al., 20I6), mangroves (Hu et al., 20I5), salt environments (Evelin et al., 2009; Elhindi et al., 2017), among others. However, occurrence of the symbiosis and AMF development depend on the characteristics of the environment such as soil pH, soil type, climate, stage of forest succession, host species and level of mycorrhizal dependence of host species. Plants are believed to be dependent on AMF colonization because the decrease in AMF richness results in decrease of plant species richness (Gange et al., 1993).

In Brazil, experiments in nursery and field conditions have confirmed the potential of using AMF inoculants to stimulate seedling growth, plant nutrient uptake and yields of planted forests (Marinho et al., 2004; Schiavo et al., 2010; Mello et al., 2012; Lima; Sousa, 20I4) because AMF inoculation facilitates the dynamic process of colonization by AMF species. In fact, the AMF morphotype to be employed as AMF inoculant should be effective to promote plant growth, increase the plant tolerance to environmental stresses, but they need to be competitive against indigenous AMF species (e.g. Séry et al., 2016; Vilcatoma-Medina et al., 2018). In spite of several experiments, it remains unresolved which of the AMF species that would be the most appropriated to be employed as AMF inoculant in many forest species (e.g. Vilcatoma-Medina et al., 2018). Knowledge on which AMF species are dominating a forest ecosystem may help target better strategies of AMF selection, production and inoculation with potential beneficial returns to the ecosystem. Therefore, the objective of this review is to compile information to identify existing patterns in AMF diversity in Brazilian forest ecosystems.

\section{Literature Gathering}

Initially, it was searched for articles that contained the keywords "biodiversity", "mycorrhizal" and "Brazil" and the respective Portuguese translations ("biodiversidade", "micorriza" and "Brasil") in the data base Web of Science, Portal de Periódicos Capes/MEC (http://www-periodicos-capes-gov-br.ez22.periodicos. capes.gov.br/). Among the selected articles of the first round, the articles that investigated AMF associated with forest plant species or forest ecosystems, and that were peer-reviewed were selected $(n=958)$. Then, articles were selected that contained taxonomic identification of 
AMF species based on spore morphology (e.g. taxonomical classification as proposed by Redecker et al. 2013). The approach of using spore morphology was chosen to ensure that the comparison among different ecosystems was fair. Our first browsing pointed out that molecular tools are identifying a much larger number of species than the traditional microscope methods (spore morphology), and therefore, changes in diversity would not be explained by the ecosystem but by the AMF identification method. In addition, spores identified only by their putative genus had to be excluded (e.g. Glomus sp. I, Glomus sp. 2, Glomus sp. 3 ...) because there was no control on the possible overlapping of species found in different studies.

Literature research resulted in the data compilation of 74 articles describing AMF diversity in Brazilian forest ecosystems, which were published between January 1997 and August 2018 in the English, Portuguese or Spanish languages. Details of the individual experiments are given in the list of Supplementary Material.

Selected articles considered the homepage <http://www.amf-phylogeny.com/> for taxonomy and phylogeny, with a list of more than 400 species of AMF species. The articles of Brazilian forest ecosystems reported the occurrence of at least 164 AMF species, without considering those that were only identified at genus level (Supplementary Material). However, it is likely that diversity would be much greater if AMF identity was based on molecular dissimilarities (Vieira et al., 2017).

The taxonomy of AMF spores based on the primary, secondary and tertiary layers of the spore wall, the germinative walls and the germination structures (Morton et al., 1995) is not an expensive approach, when the researcher is already trained in identifying spore structures under the microscope. However, the discovery of new species leading to questions on the current phylogeny and the lack of lab expertise to recognize the spore structures make the morphological identification a challenge. On the other hand, DNA sequencing, which is a more objective approach despite not being cheap and fully developed, could also identity AMF. In that case, two overlapping sequences of nuclear DNA -the smaller subunit (SSU) in the internal transcribed spacer (ITS) region and the larger subunit (LSU) in the ribosomal DNA (rDNA), targeted by a mixture of primers, are strong candidate genetic regions for distinguishing AMF species (Krüger et al., 2009). However, probably due to the small number of available sequences of all AMF species (Krüger et al., 20I4) and perhaps due to failure in sequencing all possible individuals in the environment, even molecular tools cannot embrace the whole AMF diversity environmental samples (Vasar et al., 2017).
Occurrence of AMF morphotypes in Brazilian biomes

Brazil encompasses six major terrestrial biomes: Amazon Forest, Atlantic Forest, Cerrados (Brazilian savannas), Caatinga, Pantanal and Pampas (highlands grasslands) (IBGE, 2004). Biome is a set of contiguous types of vegetation, recognizable in regional scale, with similar geographic and climatic conditions and history of changes, which results in a particular biological diversity. Because each biome sustains a particular group of plants, it was supposed that AMF diversity in each host plant would be specifically related to each biome.

The AMF were distributed in the six biomes as follows: I 32 in Amazon Forest, 101 in Atlantic Forest, 87 in Cerrados, 63 in Caatinga, 19 in Pantanal and 5 in Pampa. The Atlantic Forest and the Caatinga concentrated 74\% of the studies, which shows that studies with mycorrhizal symbiosis is still incipient in Brazil. Pantanal, Pampa, Amazon Forest and Cerrado had, respectively, I, I, 7 and 7 papers on diversity of published AMF. The list of AMF encountered in the 78 papers considered in this review probably underestimated the diversity of species that can be found in Brazilian biomes.

The first important finding of this research is that AMF species are not plant host specific but are selected by the environmental conditions where the host grows. In addition, the research listed a large number of species in different forest ecosystems (plant rhizosphere and biome) making it possible to point out ubiquitous and rare species (Table I). In this paper, ubiquitous species were those found in two or more biomes while rare species were those found in only one biome. Many AMF species were considered to be ubiquitous but a few of them were considered rare (Table I).

Sesbania virgata was the host plant with lower number of diferent AMF species. The AMF Dominikia aurea and Racocetra alborosea occurred only in Manilkara zapota, Funneliformis caledonium and Rhizoglomus arabicum only in Mimosa tenuiflora and Glomus multisubstensum in Eucalytus spp., but we cannot confirm whether they are rare species. Rare AMF species may be an artefact of AMF identification because, in comparison to molecular tools, spore morphology may underestimate AMF diversity. In addition, the AMF Acaulospora minuta, Glomus nanolumen, Glomus pansihalos and Paraglomus pernambucanum occurred in some forest ecosystems, but they were not related with a specific host plant. They could be rare AMF species, althougth not specific to a host plant. 
TABLE I Occurrence of Arbuscular Mycorrhizal Fungi (AMF) species in hosts from native and planted forests in Brazilian ecosystems. Data compilation included papers showing AMF identification based on spore morphology that were published during the period from 1997 January to 2018 August. Papers relating diversity on the basis of molecular analyses are cited throughout the manuscript.

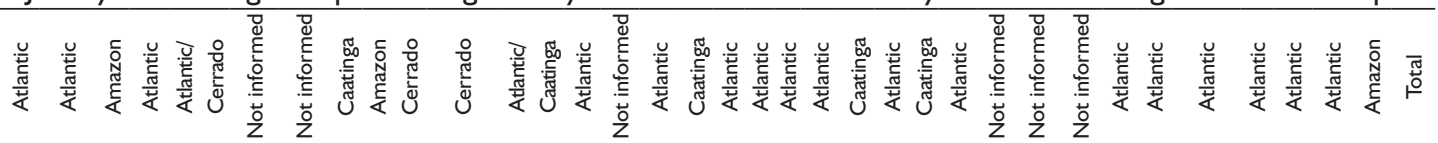

Plant Host
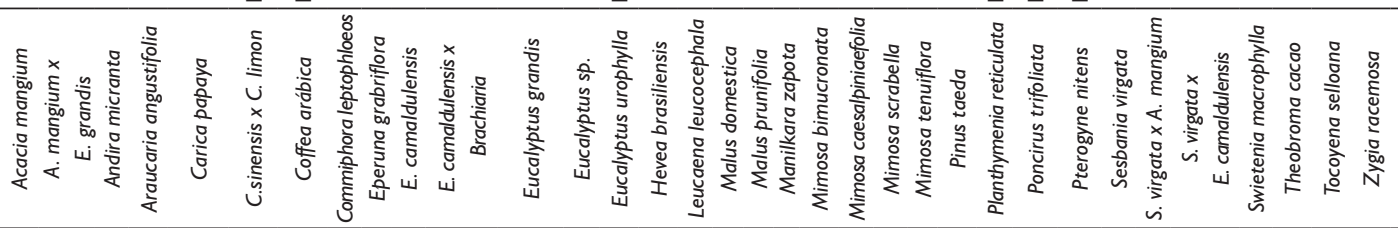

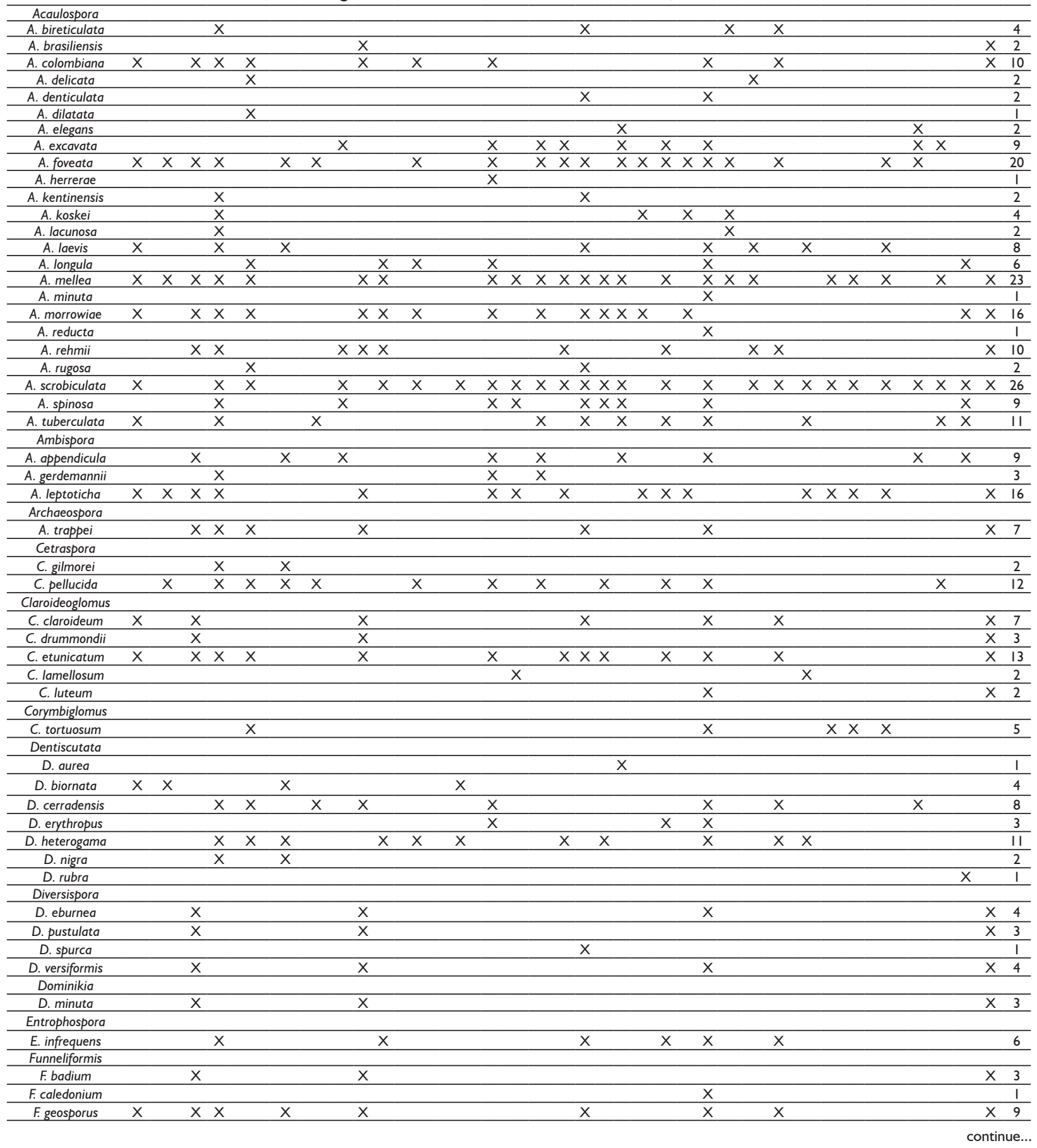


$-7 m i n \mid m$ in

WIHIH!)

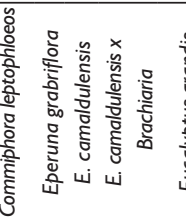

MIIIIIIIII)

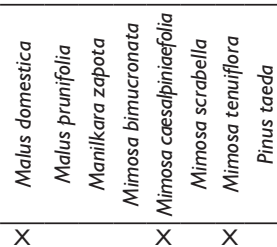

ПIIIIIIII

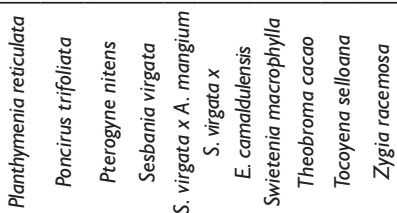

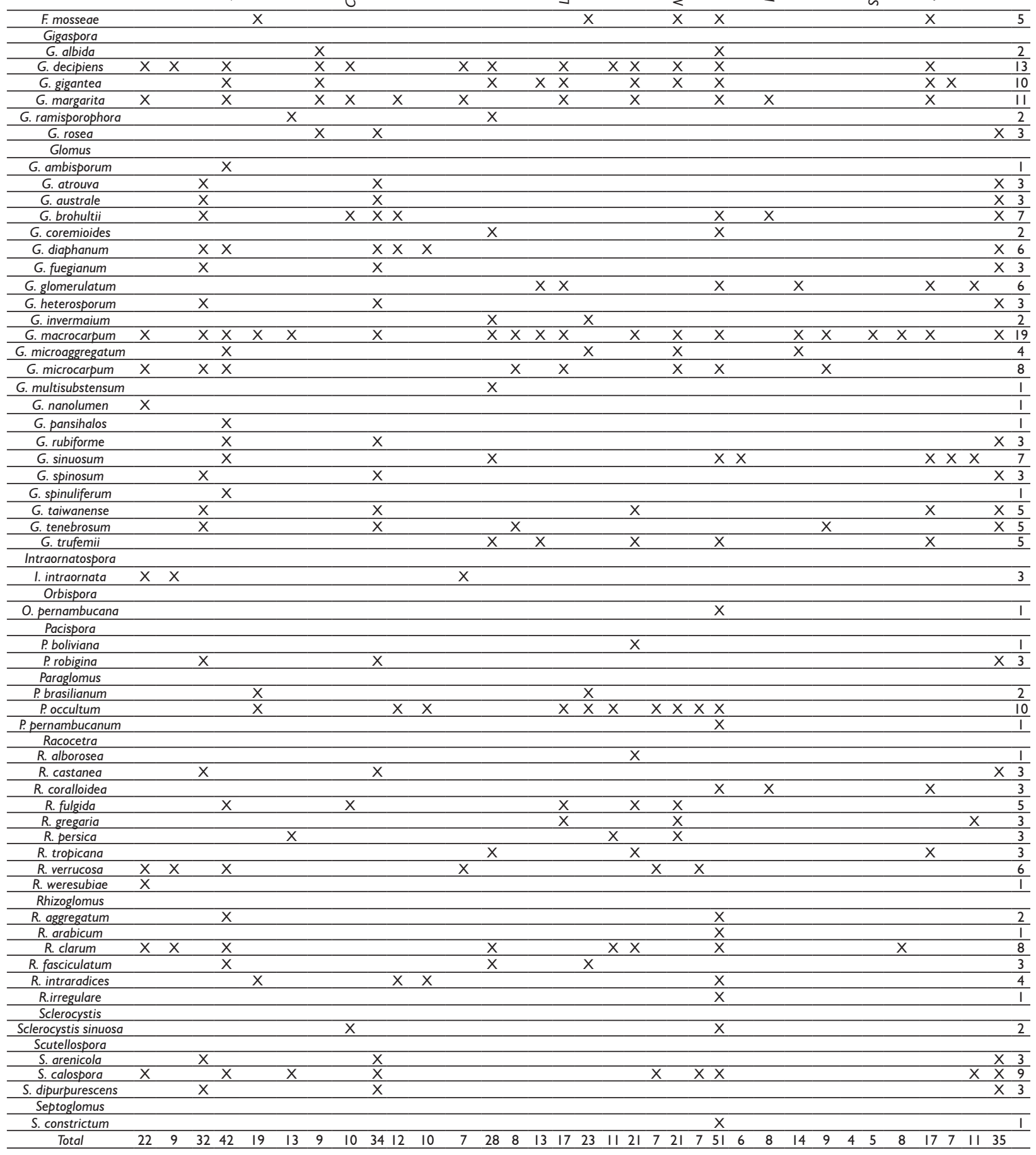
Sources: Araujo et al. (2007); Bini et al. (2017); Breuninger et al. (2000); Caproni et al. (2005); Carrenho et al. (1998); Cavallazzi et al. (2007); Fernandes et al. (2016); Focchi et al. (2004); Freitas et al. (20l4); Gomes and Trufem (1998); Lammel et al. (2015); Leal et al. (2016); Mello et al. (2006); Moreira et al. (2007); Moreira et al. (2009); Moreira-Souza et al. (2003); Pagano et al. (2009); Pagano and Scotti (2008); Pereira et al. (2014); Pontes et al. (20I7); Purin et al. (2006); Santos et al. (20I3); Silva et al. (2007); Silva et al. (20l4); Souza et al. (20I0); Souza et al. (20I6); Teixeira et al. (2017); Teixeira-Rios et al. (2018); Trindade et al. (2006); Vilcatoma-Medina et al. (2018); Zandavalli et al. (2008). 
The AMF species Acaulospora dilatata, Acaulospora herrerae, Acaulospora reducta, Dentiscutata rubra, Diversispora spurca, Glomus ambisporum, Paraglomus pernambucana, Pacispora boliviana, Racocetra weresubiae, Rhizoglomus irregulare and Septoglomus constrictum occurred in more than one biome and, despite being associated with a specific host plant, they could be considered ubiquitous (Table I). Furthermore, the AMF species Acaulospora foveata, Acaulospora mellea, Acaulospora scrobiculata, Glomus macrocarpum were widely distributed and in the Atlantic Forest, Amazon Forest, Cerrado and Caatinga biomes (Table I) and, therefore, they were considered ubiquitous AMF species.

A. foevata was found in areas of commercial reforestation of Pinus taeda (Zandavalli et al., 2008), in areas with Eucalyptus grandis (Pagano; Scotti, 2008), E. camaldulensis (Pagano et al., 2009), E. urophylla (Santos et al., 20I3). G. macrocarpum occurred in commercial forest species of $E$. camaldulensis, $E$. grandis, $M$. domestica, $M$. prunifolia, $P$. taeda and $S$. virgata, in both monocultures and consortium forest plantations (Table I). It is possible to suggest that $A$. foveata and $G$. macrocarpum are AMF species more resistant to soil environmental changes, and, they could be candidates for AMF selection.

Distribuition of AMF species should not be explained only based on host plant or biome probably because plants and microbial soil communities have close relationships that are associated with the soil fertility (Van Der Heijden et al., 2008; Burns et al., 20 I5; Bonfim et al., 2016; Casazza et al., 2017). AMF diversity can be lower and more homogeneous in fertile soils having high N/P ratio (Kikvidze et al., 20I0). However, plant roots and AMF development adjust physiologically and morphologically according to the availability of $\mathrm{P}$ (Ushio et al., 20I5, Vilcatoma-Medina et al., 20I8). In addition, soil $\mathrm{pH}$ also plays a significant role in the AMF community by altering the diversity of AMF (Kawahara et al., 2016, Vilcatoma-Medina et al., 2018) probably by changes in availability of $\mathrm{Al}$, Fe and Mn. Excess of these elements also changes the AMF community favoring the adapted AMF in the region (Silva et al., 2005). Therefore, the patterns of AMF diversity in a forest ecosystem are defined by the combination of host identity and environmental conditions where the host grows.

\section{Forestry successions}

AMF have an important role in forest succession as they impact on the competition and diversity of forest species (Zangaro et al., 2000; Zangaro et al., 2016) mainly at the beginning of the succession (Gange et al., 1993).
Indeed, Janos (1980a, 1980b) hypothesized that forest species in initial ecological sequences are less dependent on mycorrhizae than late successional species (Janos, 1980a) while pioneer forest species are not mycotrophic (Janos, 1980b). Forests of late succession need more efficient mechanisms in the cycling of nutrients than the initial forests with a higher index of plant species depending on AMF and greater symbiosis (Janos, 1980a; Rowe et al., 2007). However, other studies have indicated that tree species of initial ecological sequences have a greater presence of AMF species in relation to the climax (late) sequences, especially when mycotrophic forest species are present (Zangaro et al., 2000; Uibopuu et al., 2009). In fact, microbial symbionts (AMF) have positive and important effects on plant communities(Schuldt et al., 2017).

Climax forest species have higher nutrient reserves in seeds and slower growth than pioneer forest species (Zangaro et al., 2000). Climax forest species are benefited from shading in initial growth and once the root system is developed, they have greater absorption of nutrients from the environment without the need of sustaining the AMF symbiosis (Zangaro et al., 2000). Greater abundance AMF spores at the beginning of the forest succession may occur because plants need to establish rapidly and mycorrhizal symbiosis is beneficial (Zangaro et al., 2000). On the other hand, lower abundance of AMF spores in forests of climax succession may be associated with higher production of mycelium than sporulation (Stürmer; Siqueira, 20I I) although the process of AMF sporulation may not be correlated with time of revegetation (Bonfim et al., 2013). In this review, only II out the 75 papers identified the forest succession of the study area. Table 2 lists the distribution of 76 AMF species into three types of succession: primary, secondary and climax.

It is interesting to notice that Acaulospora scrobiculata and Claroideoglomus etunicatum, regarded as ubiquitous species (Table I), have occurred in all successions (Table 2). Therefore, in addition to $A$. foveata and $G$. macrocarpum, A. scrobiculata and $C$. etunicatum also could have potential to be used as AMF inoculant in forest species.

The fact that few AMF species can be found in different succession stages is rather important. In climax forests, climax plant species do not require support from AMF symbiosis (e.g. Zangaro et al., 2000). But, when the forest system is disturbed and the environment is unfavorable for plant growth, plants are no longer self-sufficient and should stimulate the formation of AMF symbiosis. AMF symbiosis should increase the 
competitiveness of pioneer plant species over nonpioneer plant species. However, hardness of competition is more associated to the sensitivity of AMF species to the environmental changes than to the size of AMF diversity (Mcguire et al., 2008; Shi et al., 2016). Therefore, even if an environment is intensively managed, the ecosystem may offer the necessary symbiosis for the environment restoration (Uibopuu et al., 2009). Our suggestion is that strategies to use AMF inoculants should consider AMF species that are capable to grow and to survive under different forest succession stages.

Furthermore, although time is considered an inherent dimension when studying the primary succession (Kikvidze et al., 20l0), this factor must be considered in the comparisons of diversity, as well as the spatial dimension and the mean. The time required to reach a climax forest in different forest ecosystems varies greatly, from about 30 years in a tropical forest to hundreds of years in boreal forests. Studies with primary successions use as a model areas originated from volcanic eruptions or even sand dunes aged about 300 years (Kikvidze et al., 20I0).

Diversity and occurrence of AMF in cultivated forests

Some ubiquitous AMF species, such as $A$. foveata, A. mellea, A. scrobiculata, G. macrocarpum and $C$. etunicatum (Table I and Table 2), could have an adaptation function in degraded areas as well as in seedling that are transplanted in cultivated forests. Other AMF species have been mentioned in literature for AMF inoculants. For example, G. viscosum for wet and adensed soils (Bonfim et al., 20I3). The study involved a native forest area (NT, G. macrocarpum for $A$. mangium seedlings (Schiavo et al., 20I0), A. scrobiculata (Cavallazzi et al., 2007), A. scrobiculata together with other AMFs (Machineski et al., 2009).

Therefore, application of mycorrhizal inoculants in forest nursery seedlings can be a strategy to stimulate the development and establishment of seedlings in the field. Indeed, the inoculation of AMF inoculant in clay pots was important for the Acacia mangium after 45 to 220 days of transplanting to the field (Schiavo et al., 2010). Inoculated plants of Acacia auriculiformes also showed higher survival, higher shoot biomass and height than noninoculated plants (Giri et al., 2004). However, silvicultural management has strong effects on mycorrhizal community of forest ecosystems (Campos et al., 20I I). For example, the application of fertilizers during revegetation increased the density of AMF spores in the soil (Marinho et al., 2004).
TABLE 2 Richness of AMF species associated with forestry ecological succession in the Brazilian territory, in papers that were published in the period of January 1997 to August 2018.

\begin{tabular}{|c|c|c|c|}
\hline \multirow{2}{*}{ AMF species } & \multicolumn{3}{|c|}{ Succession } \\
\hline & Early & Secundary & Climax \\
\hline Acaulospora bireticulata & & 1 & 1 \\
\hline Acaulospora capsicula & & 1 & 1 \\
\hline Acaulospora colombiana & & 9 & 2 \\
\hline Acaulospora delicata & & 5 & 3 \\
\hline Acaulospora elegans & & 2 & \\
\hline Acaulospora excavata & & 3 & 1 \\
\hline Acaulospora foveata & & 11 & 3 \\
\hline Acaulospora gedanensis & & 2 & 1 \\
\hline Acaulospora herrerae & 1 & 1 & 1 \\
\hline Acaulospora koskei & & & $\mathrm{I}$ \\
\hline Acaulospora lacunosa & & 2 & \\
\hline Acaulospora laevis & & & $\mathrm{I}$ \\
\hline Acaulospora longula & $\mathrm{I}$ & $\mathrm{I}$ & 2 \\
\hline Acaulospora mellea & & 9 & 3 \\
\hline Acaulospora morrowiae & & 7 & $\mathrm{I}$ \\
\hline Acaulospora paulinae & & $\mathrm{T}$ & \\
\hline Acaulospora polonica & & $\mathrm{I}$ & \\
\hline Acaulospora rehmii & & 4 & \\
\hline Acaulospora rugosa & & $\mathrm{I}$ & 1 \\
\hline Acaulospora scrobiculata & 1 & 9 & 4 \\
\hline Acaulospora spinosa & & 4 & 3 \\
\hline Acaulospora tuberculata & & 5 & 2 \\
\hline Acaulospora walkeri & & 4 & 1 \\
\hline Ambispora appendicula & & & 1 \\
\hline Ambispora gerdemannii & & & $\mathrm{I}$ \\
\hline Ambispora leptoticha & & 4 & 1 \\
\hline Archaeospora trappei & & 6 & $\mathrm{I}$ \\
\hline Cetraspora pellucida & & 4 & 2 \\
\hline Claroideoglomus claroideum & 1 & 4 & $\mathrm{I}$ \\
\hline Claroideoglomus etunicatum & 1 & 6 & 3 \\
\hline Claroideoglomus luteum & & $\mathrm{I}$ & 1 \\
\hline Corymbiglomus corymbiforme & & 1 & $\mathrm{I}$ \\
\hline Corymbiglomus tortuosum & & 2 & $\mathrm{I}$ \\
\hline Dentiscutata biornata & & 1 & \\
\hline Dentiscutata cerradensis & & 1 & \\
\hline Dentiscutata erythropus & & $\mathrm{I}$ & \\
\hline Dentiscutata heterogama & & 2 & 1 \\
\hline Dentiscutata scutata & & & 1 \\
\hline Diversispora spurca & & 2 & \\
\hline Diversispora trimurales & & 1 & \\
\hline Entrophospora infrequens & & 4 & 2 \\
\hline Funneliformis geosporus & & 4 & 1 \\
\hline Funneliformis mosseae & & $\mathrm{I}$ & $\mathrm{I}$ \\
\hline Funneliformis verruculosum & & 2 & \\
\hline Gigaspora decipiens & & 1 & $\mathrm{I}$ \\
\hline Gigaspora gigantea & & 2 & $\mathrm{I}$ \\
\hline Gigaspora margarita & & 1 & 3 \\
\hline Gigaspora ramisporophora & & $\mathrm{I}$ & \\
\hline Glomus albidum & & $\mathrm{I}$ & $\mathrm{I}$ \\
\hline Glomus ambisporum & & 2 & \\
\hline Glomus australe & & 2 & $\mathrm{I}$ \\
\hline Glomus clavisporum & & 4 & 2 \\
\hline Glomus coremioides & & 2 & \\
\hline Glomus diaphanum & & 2 & $\mathrm{I}$ \\
\hline Glomus fuegianum & & $\mathrm{I}$ & \\
\hline Glomus glomerulatum & & 3 & 1 \\
\hline Glomus hoi & & $\mathrm{I}$ & $\mathrm{I}$ \\
\hline Glomus invermaium & & 2 & $\mathrm{I}$ \\
\hline Glomus lacteum & & 2 & 1 \\
\hline Glomus macrocarpum & $\mathrm{I}$ & 8 & 4 \\
\hline Glomus magnicaule & & $\mathrm{I}$ & $\mathrm{I}$ \\
\hline Glomus microaggregatum & & 4 & 1 \\
\hline Glomus microcarpum & & 1 & 2 \\
\hline Glomus rubiforme & & $\mathrm{I}$ & \\
\hline Glomus sinuosum & & 2 & $\mathrm{I}$ \\
\hline Intraornatospora intraornata & & 1 & \\
\hline Paraglomus occultum & & $\mathrm{I}$ & 1 \\
\hline Racocetra fulgida & 1 & 1 & \\
\hline Racocetra pérsica & & $\mathrm{I}$ & \\
\hline Racocetra verrucosa & & & $\mathrm{I}$ \\
\hline Rhizoglomus aggregatum & & $\mathrm{I}$ & \\
\hline Rhizoglomus clarum & & 5 & \\
\hline Rhizoglomus intraradices & & 1 & $\mathrm{I}$ \\
\hline Scutellospora aurigloba & $\mathrm{I}$ & & \\
\hline Scutellospora calospora & & & 2 \\
\hline Septoglomus constrictum & & 1 & 1 \\
\hline Total Abundance & 8 & 186 & 80 \\
\hline
\end{tabular}

Sources: Gomes and Trufem (1998); Focchi et al. (2004); Leal et a (2009); Moreira et al. (2009); Silva et al. (2016); Souza et al. (2003); Sousa et al. (2014); Stürmer and Siqueira (201 I); Teixeira et al. (2017); Vieira et al. (2017); Zangaro et al. (2013). 
Therefore, in addition to AMF inoculants, it is important that soil chemical amendments should be part of the strategies to improve forest establishment.

\section{CONCLUSIONS}

The AMF species are not specific plant host but are selected by the environmental conditions where the host grows, but some are ubiquitous and some are rare AMF species in forest ecosystems. Four AMF species: Acaulospora scrobiculata, Acaulospora foveata, Acaulospora mellea, Clareoideglomus etunicatum and Glomus macrocarpum are ubiquitous and adapted to different managements. Therefore, these AMF species could have potential to be used as AMF inoculant in forest species.

\section{AKNOWLEDGEMENTS}

The authors aknowledge suggestions from the discussion group in Soil Quality, Fabiane Machado Vezzani, Jéssica Pereira de Souza, Tatiana Suzin Lazeris, Raphael Anzalone, Angela Hikeda and Dione Aguiar. E. Winagraski and P.H.R. Monteiro aknowledge the schorlarship from CAPES (Coordination of Improvement of Higher Level Personnel) from Brazil.

\section{REFERENCES}

ARAUJO, Q. R.; ALMEIDA, O. C.; SANTANA, S. O.; GOTO, B. T.; CAVALCANTE, U. M. T.; BEZERRA, J. L.; MARROCOS, P. C. L. Fungos micorrízicos em solos cultivados com cacau na Mata Atlântica. Agrotropica, v. 19, p.69-72, 2007.

ASSIS, D. M. A.; OEHL, F.; GONÇALVES, C.M.; SILVA, D. K. A.; SILVA, G. A. Community structure of arbuscular mycorrhizal fungi in fluvial and maritime dunes of Brazilian Northeast. Applied Soil Ecology, v. I08, p. I36-I46, 2016.

BINI, D.; SANTOS, C. A.; SILVA, M. C. P.; BONFIM, J. A.; CARDOSO, E. J. B. N. Intercropping Acacia mangium stimulates AMF colonization and soil phosphatase activity in Eucalyptus grandis. Scientia Agricola, v. 75, n. 2, p. I02-I 10, 2017.

BONFIM, J. A.; VASCONCELLOS, R. L. F; GUMIERE, T.; MESCOLOTTI, D. L. C.; OEHL, F;; CARDOSO, E. J. B. N. Diversity of Arbuscular Mycorrhizal Fungi in a Brazilian Atlantic Forest Toposequence. Microbial Ecology, v. 7I, p. I64-177. 2016.

BONFIM, J. A.; VASCONCELLOS, R. L. F.; STÜRMER, S. L.; CARDOSO, E. J. B. N. Arbuscular mycorrhizal fungi in the Brazilian Atlantic forest: A gradient of environmental restoration. Applied Soil Ecology, v, 7I, p.7-14, 2013.

BREUNINGER, M.; EINING, W.; MAGEL, E.; CARDOSO, E.; HAMPP, R. Mycorrhiza of Brazil Pine (Araucaria angustifolia (Bert. O. Ktze.). Plant Biology, v. 2, p. 4-10, 2000.
BRUNDRETT, M. C. Coevolution of roots and mycorrhizas of land plants. New Phytologist, v. I54, p.275-304, 2002.

BURNS, J. H; ANACKER, B. L; STRAUSS, S. Y; BURKE, D. J. Soil microbial community variation correlates most strongly with plant species identity, followed by soil chemistry, spatial location and plant genus. AoB PLANTS, v. 7, p. I-10, 2015.

CAMPOS, D. T. S.; SILVA, M. C. S. S.; LUZ, J. M. R.; TELESFORA, R. J.; KASUYA, M. C. M. Colonização micorrízica em plantios de eucalipto. Árvore, v. 35, p.965-974, 20 I I.

CAPRONI, A. L.; FRANCO, A. A.; BERBARA, R. L. L.; GRANHA, J. R. D. O.; MARINHO, N. F. Fungos Micorrízicos Arbusculares em estéril revegetado com Acacia mangium, após mineiração de bauxita. Árvore, v. 29, n. 3, p.373-38I, 2005.

CARRENHO, R.; TRUFEM, S. F. B.; BONONI, V. L. R. Arbuscular mycorrhizal fungi in Citrus sinensis/ $C$. limon treated with Fosetyl-Al and Metalaxyl. Mycological Research, v. I02, n. 6, p.677-682, 1998.

CASAZZA, G.; LUMINI, E.; ERCOLE, E.; DOVANA, F.; GUERRINA, M.; ARNULFO, A.; MINUTO, L.; FUSCONI, A.; MUCCIARELLI, M. The abundance \& diversity of arbuscular mycorrhizal fungi are linked to the soil chemistry of screes \& to slope in the Alpic paleo-endemic Berardia subacaulis. PLoS ONE, v. I2, p.I-19, 2017.

CAVALLAZZI, J. R. P.; KLAUBERG FILHO, O.; STÜRMER, S. L.; RYGIEWICZ, P. T.; MENDONÇA, M. M. Screening and selecting arbuscular mycorrhizal fungi for inoculating micropropagated apple rootstocks in acid soils. Plant Cell, Tissue and Organ Culture, v. 90, p. I I7-129, 2007.

ELHINDI, K. M.; EL-DIN, A. S.; ELGORBAN, A. M. The impact of arbuscular mycorrhizal fungi in mitigating salt-induced adverse effects in sweet basil (Ocimum basilicum L.). Saudi Journal of Biological Sciences, v. 24, p. I70-179, 2017.

EVELIN, H.; KAPOOR, R.; GIRI B. Arbuscular mycorrhizal fungi in alleviation of salt stress: A review. Annals of Botany, v. I04, p. I263-1280, 2009.

FERNANDES, R. A.; FERREIRA, D. A.; SAGGIN-JUNIOR, O. J.; STÜRMER, S. L.; PAULINO, H. B.; SIQUEIRA, J. O.; CARNEIRO, M. A. C. Occurrence and species richness of mycorrhizal fungi in soil under different land use. Canadian Journal of Soil Science, v. 96, p. 27I-280, 2016.

FOCCHI, S. S.; SOGLIO, F. K. D.; CARRENHO, R.; SOUZA, P. V. D.; LOVATO, P. E. Fungos micorrizicos arbusculares em cultivos de citros sob manejo convencional e orgânico. Pesquisa agropecuária brasileira, v. 39, n. 5, p.469-476, 2016.

FREITAS, R. O.; BUSCARDO, E.; NAGY, L.; MACIEL, A. B. S.; CARRENHO, R.; LUIZÃO, R. C. C. Arbuscular mycorrhizal fungal communities along a pedo-hydrological gradient in a Central Amazonian terra firme forest. Mycorrhiza, v. 24, p. $21-32,2014$. 
GANGE, A. C.; BROWN, V. K.; SINCLAIR, G. S. Vesiculararbuscular mycorrhizal fungi: a determinant of plant community structure in early succession. Functional Ecology (United Kingdom), v. 7, p.616-622, 1993.

GIRI, B.; KAPOOR, R.; AGARWAL, L.; MUKERJI, K. G. Preinoculation with arbuscular mycorrhizae helps Acacia auriculiformis grow in degraded Indian wasteland soil. Communications in Soil Science and Plant Analysis, v. 35, p. 193-204, 2004

GOMES, S. P.; TRUFEM, S. F. B. Fungos micorrízicos arbusculares (Glomales, Zygomycota) na ilha dos eucaliptos, repressa do Guarapiranga, São Paulo, SP. Acta botânica brasílica, v. I2, n. 3, p. 393-40I, 1998.

HU, W.; WU, Y.; XIN, G.; WANG, Y.; GUO, J.; PENG, X. Arbuscular mycorrhizal fungi and their influencing factors for Aegiceras corniculatum and Acanthus ilicifolius in southern China. Pakistan Journal of Botany, v. 47, p.|58I-I586, 2015.

IBGE - INSTITUTO BRASILEIRO DE GEOGRAFIA E ESTATÍSTICA. Mapa de Biomas do Brasil: Primeira aproximação. Rio de Janeiro: IBGE, 2004. I mapa, colorido. Escala 1:5.000.000. Available at: htttp://geoftp.ibge.gov.br/ mapas/tematicos/mapas murais/biomas.pdf $>$. Accessed in: April I5th 2018.

JANOS, D. P. Vesicular-Arbuscular Mycorrhizae Affect Lowland Tropical Rain Forest Plant Growth. Ecology, v. 6I, p. I5I162, 1980a.

JANOS, D. P. Mycorrhizae influence tropical succession. Biotropica, v. 12, p. 56-64, v. 1980 b.

KAWAHARA, A.; AN, G.; MIYAKAWA, S.; SONODA, J.; EZAWA, T. Nestedness in Arbuscular Mycorrhizal Fungal Communities along Soil pH Gradients in Early Primary Succession: Acid-Tolerant Fungi Are pH Generalists. Plos One, v. II, p. I-20, 2016.

KIKVIDZE, Z.; ARMAS, C.; FUKUDA, K.; MARTÍNEZ-GARCÍA, L. B.; MIYATA, M.; ODA-TANAKA, A.; PUGNAIRE, F. I.; $\mathrm{WU}, \mathrm{B}$. The role of arbuscular mycorrhizae in primary succession: Differences and similarities across habitats. Web Ecology, v. 10, p. 50-57, 2010.

KRÜGER, M.; STOCKINGER, H.; KRÜGER, C.; SCHÜßLER, A. DNA-based species level detection of Glomeromycota: One PCR primer set for all arbuscular mycorrhizal fungi. New Phytologist, v. 183, p. 2I 2-223, 2009.

KRÜGER, C.; WALKER, C.; SCHÜßLER, A. Scutellospora savannicola: redescription, epitypification, DNA barcoding and transfer to Dentiscutata. Mycological Progress, v. I 3, p. I I65-I|78, 2014.

LAMMEL, D. R.; CRUZ, L. M.; MESCOLOTTI, D.; STÜRMER, S. L; CARDOSO, E. J. B. N. Woody Mimosa species are noduleted by Burkholderia in ombrophylous forest soils and their symbioses are enhanced by arbuscular mycorrhizal fungi (AMF). Plant Soil, v.393, n. I-2, p.I23-I35, 2015.
LEAL, P. L.; STÜRMER, S. L.; SIQUEIRA, J. O. Occurence and diversity of arbuscular mycorrhizal fungi in trap cultures from soils under different land use systems in the Amazon, Brazil. Brazilian Journal of Microbiology, v. 40, p. I I I- I 2 I, 2009.

LEAL, P. L.; VARÓN-LÓPEZ, M.; PRADO, I. G. O.; SANTOS, J. V.; SIQUEIRA, J. O.; MOREIRA, F. M. S. Enrichment of arbuscular mycorrhizal fungi a contaminated soil after rehabilitation. Brazilian Journal of Microbiology, v.47, p.853-862, 2016.

LIMA, F. S.; SOUSA, C. S. Crescimento e nutrição de mudas de clones de eucalipto com fungos micorrízicos. Pesquisa Agropecuaria Tropical, v. 44, p. II0-1 18, 2014.

MACHINESKI, O.; BALOTA, E. L.; COLOZZI FILHO, A.; SOUZA, D. A; SOUZA, J. R. P. Crescimento de mudas de peroba rosa em resposta à inoculação com fungos micorrízicos arbusculares. Ciência Rural, v. 39, p.567-570, 2009.

MARINHO, N. F.; CAPRONI, A. L.; FRANCO, A. A.; BERBARA, R. L. L. Respostas de Acacia mangium Willd e Sclerolobium paniculatum Vogel a fungos micorrízicos arbusculares nativos provenientes de áreas degradadas pela mineração de bauxita na Amazônia. Acta Botanica Brasilica, v.18, p.|4|-|49, 2004.

MCGUIRE, K. L.; HENKEL, T. W.; GRANZOW DE LA CERDA, I.; VILLA, G.; EDMUND, F; ANDREW, C. Dual mycorrhizal status of non-dominant tree and liana species. Mycorrhiza, v.18., n.4, p.217-222, 2008.

MELLO, C. M. A.; RAMALHO, I.; PONTES, J. S.; GOTO, B. T.; SILVA, G. A; MAIA, L.C. Diversidade de fungos micorrízicos arbusculares em área de Caatinga, PE, Brasil. Acta Botanica Brasilica, v.26; p.938-943, 2012.

MELLO, A. H.; ANTONIOLLI, Z. I.; KAMINSKI, J.; SOUZA, E. L.; OLIVEIRA, V. L. Fungos arbusculares e ectomicorrízicos em áreas de eucalipto de campo nativo em solo arenoso. Ciência Florestal, v. I6, n. 3, p.293-30I, 2006.

MOREIRA, M.; BARETTA, D.; TSAI, S. M.; CARDOSO, E. J. B. N. Arbuscular mycorrhizal fungal communities in native and in replanted Araucaria forest. Scientia Agricola, v. 66, n. 5, p. 677-684, 2009.

MOREIRA, M.; NOGUEIRA, M. A.; TSAI, S. M.; GOMES-DACOSTA, S. M.; CARDOSO, E. J. B. N. Sporulation and diversity of arbuscular mycorrhizal fungi in Brazil Pine in the field and in the greenhouse. Mycorrhiza, v. 17, p. 519-526, 2007.

MOREIRA-SOUZA, M.; TRUFEM, S. F. B.; GOMES-DA-COSTA, S. M.; CARDOSO, E. J. B. N. Arbuscular mycorrhizal fungi associated with Araucaria angustifolia (Bert.) O. Ktze. Mycorrhiza, v. I3, p. 2II-215, 2003.

MORTON, J. B.; BENTIVENGA, S. P.; BEVER, J. D. Discovery, measurement, and interpretation of diversity in symbiotic endomycorrhizal fungi. Canadian Journal of Botany, v.73, p 25-32, 1995. 
PAGANO, M. C.; SCOTTI, M. R. Arbuscular and ectomycorrhizal colonization of two Eucalyptus species in semiarid Brazil. Mycoscience, v. 49, p. 379-384, 2008.

PAGANO, M. C.; SCOTTI, M. R.; CABELLO, M. N. Effect of the inoculation and distribution of mycorrhizae in Plathymenia reticulata benth under monoculture and mixed plantation in Brazil. New Forests, v.38, p. I97-2।4, 2009.

PEREIRA, C. M. R.; SILVA, D. K. A.; FERREIRA, A. C. A.; GOTO, B. T.; MAIA, L. C. Diversity of arbuscular mycorrhizal fungi in Atlantic forest areas under different land uses. Agriculture, ecosystems and Environment, v.185, p.245-252, 2014.

PONTES, J. S.; OEHL, F.; MARINHO, F.; COYNE, D.; SILVA, D. K. A.; YANO-MELO, A.; MAIA, L. C. Diversity of arbuscular mycorrhizal fungi in Brazil's Caatinga and experimental agroecosystems. Biotropica, v.49, n. 3, p. 4I3-427, 2017.

PURIN, S.; FILHO O. K.; STÜRMER, S. L. Mycorrhizae activity and diversity in conventional and organic apple orchards from Brazil. Soil Biology and Biochemistry, v. 38, p. |83|-|839, 2006.

REDECKER, D.; SCHÜßLER, A.; STOCKINGER, H; STÜRMER, S. L.; MORTON, J. B.; WALKER, C. An evidence-based consensus for the classification of arbuscular mycorrhizal fungi (Glomeromycota). Mycorrhiza, v. 23, p. 5I5-53I, 2013.

ROWE, H. I.; BROWN, C. S.; CLAASSEN, V. P. Comparisons of mycorrhizal responsiveness with field soil and commercial inoculum for six native montane species and Bromus tectorum. Restoration Ecology, v. I5, p.44-52, 2007.

SANTOS, R. S.; SCORIZA, R. N.; FERREIRA, J. S. Fungos micorrízicos arbusculares em diferentes coberturas florestais em Vitória da Conquista, Bahia. Floresta e Ambiente, v.20, p.344-350, 2013.

SCHIAVO, J. A.; MARTINS, M. A.; RODRIGUES, L. A. Crescimento de mudas de Acacia mangium, Sesbania virgata e Eucalytpus camaldulensis, inoculadas com fungos micorrízicos, em casa-de-vegetação e em cava-de-extração de argila. Acta Scientiarum - Agronomy, v. 32, p. I7I-178, 2010.

SCHULDT, A.; BRUELHEIDE, H.; BUSCOT, F.; ASSMANN, T.; ERFMEIER, A; KLEIN, A.; MA, K.; SCHOLTEN, T.; STAAB, M.; WIRTH, C. Belowground top-down and aboveground bottom-up effects structure multitrophic community relationships in a biodiverse forest. Scientific Reports, v. 7, p. I-10, 2017

SÉRY, D. J.; KOUADJO, Z. G.; VOKO, B. R.; ZEZE, A. Selecting native arbuscular mycorrhizal fungi to promote cassava growth and increase yield under field conditions, Front Microbiology, v. 7, p.2063, 2016.

SHI, N.; GAO, C.; ZHENG, Y.; GUO, L. Arbuscular mycorrhizal fungus identity and diversity influence subtropical tree competition. Fungal Ecology, v.20, p. II5-123, 2016.

SILVA, C. F.; PEREIRA, M. G.; SANTOS, V. L.; MIGUEL, D. L.; SILVA, E. M. R. Fungos micorrízicos arbusculares:
Composição, comprimento de micélio extrarradicular e glomalina em áreas de Mata Atlântica, Rio de Janeiro. Ciência Florestal, v.26, n. 2, p. 4I9-433, 2016.

SILVA, C. F.; ARAÚJO, J. L. S.; SILVA, E. M. R.; PEREIRA, M. G.; SCHIAVO, J. A.; FREITAS, M. S. M.; SAGGIN-JUNIOR, O. J.; MARTINS, M. A. Comunidade de fungos micorrízicos arbusculares: Diversidade, composição e glomalina em área revegetada com Sesbânia. Revista Brasileira de Ciencia do Solo, v.38, p.423-43I, 2014.

SILVA, F. A.; DE ALCANTARA, I. L.; ROLDAN, P. S.; PADILHA, C. C. F.; DE ARAUJO, A. B.; VALENTE, J. P. S.; FLORENTINO, A. O.; PADILHA, P. M. Determination of $\mathrm{Hg}$ in water by CVAAS using 2-aminothiazole modified silica. Ecletica Quimica, v.30, p. 47-55, 2005.

SILVA, X. S.; FIGUEIREDO, M. V. B.; SILVA, G. A.; GOTO, B. T.; OLIVEIRA, J. P.; BURITY, H. A. Fungos micorrízicos arbusculares em áreas de plantio de leucena e sábia no estado de Pernambuco. Árvore, v. 3I , n. 3, p. 427-435, 2007.

SKUJINS, J.; ALLEN, M. F. Use of mycorrhizae for land rehabilitation. MIRCEN Journal of Applied Microbiology and Biotechnology, v. 2, p.16I-176, 1986.

SMITH, S. E.; READ, D. J. Mycorrhizal symbiosis. 3rd edn: Academic Press, 2008. 800p.

SOUSA, C. S.; MENEZES, R. S. C.; SAMPAIO, E. V. S. B.; LIMA, F. S.; MAIA, L. C.; OEHL, F. Arbuscular mycorrhizal fungi in sucessional stages of caatinga in the semi-arid region of Brazil. Ciência Florestal, v.24, n. I, p.|37-|48, 20 |4.

SOUZA, R. G.; GOTO, B. T.; SILVA, D. K. A.; SILVA, F. S. B.; SAMPAIO, E. V. S. B.; MAIA, L. C. The role of arbucular mycorrhizal fungi and cattle manure in the establishment of Tocoyena selloana Schum. in mined dune areas. European Journal of Soil Biology, v.46, p.237-242, 2010.

SOUZA, R. G.; SILVA, D. K. A.; MELLO, C. M. A.; GOTO, B. T.; SILVA, F. S. B.; SAMPAIO, E. V. S. B.; MAIA, L. C. Arbuscular mycorrhizal fungi in revegetated mined dunes. Land Degradation \& Development, v.24, p. I47-I55, 2013.

SOUZA, T. A. F.; RODRIGUEZ-ECHEVERRÍA, S.; ANDRADE, L. A.; FREITAS, H. Arbuscular mycorrhizal fungi in Mimosa tenuiflora (Willd.) Poir from Brazilian semi-arid. Brazilian Journal of Microbiology, v. 47, p. 359-366, 2016.

STÜRMER, S. L.; SIQUEIRA, J. O. Species richness and spore abundance of arbuscular mycorrhizal fungi across distinct land uses in Western Brazilian Amazon. Mycorrhizal, v.2I, p.255-267, 201 I.

TEIXEIRA, A. F. S.; KEMMELMEIER, K.; MARASCALCHI, M. N.; STÜRMER, S. L.; CARNEIRO, M. A. C.; MOREIRA, F. M. S. Arbuscular mycorrhizal fugal communities in na iron mining area and its surroundings: Inoculum potential, density, and diversity of spores related to soil properties. Ciência e Agrotecnologia, v.4I, n.5, p. 5II-525, 2017. 
TEIXEIRA-RIOS, T.; SILVA, D. K. A.; GOTO, B. T.; YANOMELO, A. M. Seasonal differences in arbuscular mycorrhizal fungal communities in two woody species dominating semiarid caatinga forests. Folia Geobotanica, v.53, n.2, p. $191-2000,2018$.

TRINDADE, A. V.; SIQUEIRA, J. O.; STÜRMER, S. L. Arbuscular mycorrhizal fungi in papaya plantations of Espirito Santo and Bahia, Brazil. Brazilian Jounal of Microbiology, v.37, p.283-289, 2006.

UIBOPUU, A.; MOORA, M.; SAKS, Ü.; DANIELL, T.; ZOBEL, M.; ÖPIK, M. Differential effect of arbuscular mycorrhizal fungal communities from ecosystems along management gradient on the growth of forest understorey plant species. Soil Biology and Biochemistry, v.4I, p.2|4|-2|46, 2009.

USHIO, M.; FUJIKI, Y.; HIDAKA, A.; KITAYAMA, K. Linkage of root physiology and morphology as an adaptation to soil phosphorus impoverishment in tropical montane forests. Functional Ecology, v 29, p. I235-1245, 2015.

VAN DER HEIJDEN, M. G. A.; BARDGETT, R. D.; VAN STRAALEN, N. M. The unseen majority: Soil microbes as drivers of plant diversity and productivity in terrestrial ecosystems. Ecology Letters, v. I I, p.296-3 10, 2008.

VAN DER HEIJDEN, M. G. A.; KLIRONOMOS, J. N.; URSIC, M.; MOUTOGLIS, P.; STREITWOLF-ENGEL, R.; BOLLER, T.; WIEMKEN, A.; SANDERS, I. R. Mycorrhizal fungal diversity determines plant biodiversity, ecosystem variability and productivity. Nature, v.74, p.69-72, 1998.

VASAR, M.; ANDRESON, R.; DAVISON, J.; JAIRUS, R.; MOORA, M.; REMM, M.; YOUNG, J. P. W.; ZOBEL, M.; ÖPIK, M. Increased sequencing depth does not increase captured diversitu of arbuscular mycorrhizal fungi. Mycorrhiza, v. 27, p.76I-773, 2017.
VIEIRA, C. K.; MARASCALCHI, M. N.; RODRIGUES, A. V.; ARMAS, R. D.; STÜRMER, S. L. Morphological and molecular diversity of arbuscular mycorrhizal fungi in revegetated iron-mining site has the same magnitude of adjacente pristine ecosystems. Journal of environmental sciences, v.67, p.330-343, 2017.

VILCATOMA-MEDINA, C. V.; KASCHUK, G.; ZANETTE, F. Colonization and spore richness of arbuscular mycorrhizal fungi in Araucaria nursery seedlings in Curitiba, Brazil. Hindawi, p. I-6, 2018.

VOZZO, J. A.; HACKSKAYLO, E. Inoculation of Pinus caribaea with ectomycorrhizal fungi in Puerto Rico. Forest science, v. 17, p. $239-245,1971$.

ZANDAVALLI, R. B.; STÜRMER, S. L.; DILLENBURG, L. R. Species richness of arbuscular mycorrhizal fungi in forests with Araucaria in Southern Brazil. Hoehnea, v. 35, p.63-68, 2008.

ZANGARO, W.; ALVES, R. A.; SOUZA, P. B.; ROSTIROLA, L. V.; LESCANO, L. E. A. M.; RONDINA, A. B. L.; NOGUEIRA, $M$. A. Succession and environmental variation influence soil exploration potential by fine roots and mycorrhizal fungi in an Atlantic ecosystem in southern Brazil. Journal of Tropical Ecology, v.30, p.237-248, 2013.

ZANGARO, W.; BONONI, V. L. R.; TRUFEN S. B. Mycorrhizal dependency, inoculum potential and habitat preference of native woody species in South Brazil. Journal of Tropical Ecology, v. 16, p. 603-622, 2000.

ZANGARO, W.; LESCANO, L. E. A. M.; MATSUURA, E. M.; RONDINA, A. B. L., NOGUEIRA, M. A. Differences between root traits of early and late successional trees influence below-ground competition and seedling estabilishment. Journal of tropical ecology, v. 32, p. I-14, 2016. 